\title{
Creating Relationships Using On-Line Dating Services: A Preliminary Mapping of French People's Views ${ }^{*}$
}

\section{Creando relaciones utilizando servicios de citas en línea: Un mapeo preliminar de los puntos de vista de los franceses}

Received: 05 January 2017 | Accepted: 17 March 2018

\author{
Mélanie GaUchéa \\ Institut Catholique de Toulouse, Francia \\ ORCID: http://orcid.org/0000-0002-3539-4463 \\ LUCIE BRARD \\ Institut Catholique de Toulouse, Francia
}

a Correspondence author. Email:
m.gauche.ict@gmail.com

How to cite: Gauché, M., \& Brard, L. (2019). Creating relationships using on-line dating services: A preliminary mapping of french people's views. Universitas Psychologica, 18(1), 1-7. https://doi.org/1 0.11144/Javeriana.upsy18-1.cruo

\begin{abstract}
We explored people's views regarding the kind of relationship that can be expected and created using such websites. In the current study, we used the same scenario technique. Vignettes depicting the kind of relationship an individual expected to find through the use of an online dating service were created by orthogonal combination of five factors: (a) passion; that is, the level of personal, affective involvement in the relationship, (b) intimacy; that is, the type of relationship desired (friendship vs. intimate/sexual), (c) commitment; that is, the expected duration of the relationship (short term vs. long term), (d) the user's gender, and (e) the user's age. Three contrasted positions were found. A minority of participants considered that creating a relationship using dating services was never very easy. A plurality of participants considered that creating either long-term romantic relationships or short-term, more "utilitarian" relationships was considerably easier than creating either short-term romantic relationships or long-term, more "utilitarian" relationships. Another plurality of participants considered that creating any relationship was quite possible. These participants disconnected the commonly admitted association between the duration of a relationship and level of emotional involvement. In other words, they considered that creating a passionate but short-lived relationship was not more difficult than creating any other kind of relationships.
\end{abstract}

Keywords

relationships; on-line dating; romantic relationships; French people.

\section{RESUMEN}

Se exploraron las opiniones de las personas con respecto al tipo de relación que puede esperarse y crearse mediante el uso de dichos sitios web. En el presente estudio, utilizamos la técnica de mismo escenario. Las viñetas que representan el tipo de relación que un individuo esperaba encontrar a través del uso de un servicio de citas en línea fueron creadas por una combinación ortogonal de cinco factores: (a) pasión; es decir, el nivel de participación personal y afectiva en la relación, (b) intimidad; es decir, el tipo de relación deseada (amistad vs. intimidad / sexual), (c) compromiso; es decir, la duración esperada de la relación (corto plazo versus largo 
plazo), (d) el sexo del usuario y (e) la edad del usuario. Se encontraron tres posiciones contrastadas. Una minoría de los participantes consideró que crear una relación a través del uso de servicios de citas no fue muy fácil. Un grupo de participantes consideró que crear relaciones románticas a largo plazo o relaciones a corto plazo, más "utilitarias" era considerablemente más fácil que crear relaciones románticas a corto plazo o relaciones a largo plazo, más "utilitarias". Otro grupo de participantes consideró que la creación de cualquier tipo de relación era bastante posible. En particular, estos participantes desconectaron la asociación comúnmente admitida entre la duración de una relación y el nivel de participación emocional, es decir, consideraron que crear una relación apasionada, pero de corta duración no era más difícil que crear cualquier otro tipo de relación.

Palabras clave

relaciones; citas en-linea; relaciones románticas; franceses.

Through internet dating, individuals can introduce themselves to other individuals they do not personally know and maintain shortterm or long-term personal relationships with them. The nature of these relationships may range from distance interactions to meetings inperson. Their objectives may range from simple companionship/friendship (e.g., to see a movie together) to intimate and sexual relationships (e.g., to involve in sadomasochistic sexual practices). Many companies worldwide provide dating services; that is, websites or applications that allow users to find individuals whose actual profile (e.g., gender, age, location, appearance, motives, personality), match the users' desired profiles.

The present study explored people's views regarding the kind of relationship that can be expected and created using such websites. Sternberg (1986) offered a typology of relationships that people may experience during their lives. His triangular model of love was based on three separate dimensions: (a) one that emphasizes the dyadic nature of love - intimacy/ sexual relationships, (b) one that emphasizes the more-than-dyadic, social nature of love commitment, and (c) one that emphasizes the personal, experienced nature of love - passion. Combinations of levels of these dimensions can, in Sternberg's view, define most kinds of relationships: (a) consummate love (passion in association with intimacy and commitment), (b) romantic love (passion in association with intimacy), (c) fatuous love (passion associated with commitment), (d) infatuated love (passion alone), (e) enduring friendship/ companionate love (intimacy associated with commitment), (f) occasional friendship (intimacy), (g) collaboration/companionship (commitment), and (h) ordinary relationship (no passion, no intimacy and no commitment). These eight kinds of relationships may be exemplified by concepts such as husband/ wife, lover, flame, coup de foudre, a long-time friend, acquaintance, colleague/collaborator, and neighbor.

Falconi and Mullet (2003) examined the algebraic nature of Sternberg's love schema using a scenario-based technique. They presented their participants with vignettes depicting a relationship between two individuals and asked them to assess the degree of true love these individuals experienced. They found that, irrespective of their participants' gender and age, the love schema was conceived as a strictly compensatory schema: Passion was the most critical factor, followed by intimacy and commitment, and a decrease in one factor (e.g., intimacy) can be compensated for by an increase in another factor (e.g., commitment). These findings have been replicated on various samples (Morales et al., 2015, Vera Cruz, 2019).

In the current study, we used the same scenario technique. Vignettes depicting the kind of relationship an individual expected to find through the use of an online dating service were created by the orthogonal combination of five factors. Three of these factors were part of Sternberg's model: (a) passion; that is, the level of personal, affective involvement in the relationship, (b) intimacy; that is, the type of relationship desired (friendship vs. intimate/ sexual), and (c) commitment; that is, the expected duration of the relationship (short term vs. long term). The two other factors were demographic: (d) the user's gender, and (e) the user's age. 
Five different questions were thus examined. Is it easier for a female than for a male to create a relationship through the internet? Is it easier for a young person than for an older person to create a relationship? Is it easier to create an intimate, sexual relationship than to create a friendly, nonsexual relationship? Is it more challenging to create a long-term relationship than to create a short-term relationship? Is it more difficult to create an affectionate, passionate relationship than to create a relationship that does not involve any strong feeling?

It has been shown that people's views regarding the quality of the relationships that can be created online are extremely controversial (Kang \& Hoffman, 2011). For some people, creating a meaningful relationship implies faceto-face meetings. As a result, successful online relationships cannot, in their views, be created (e.g., Cummings, Butler, \& Kraut, 2002). Other people are of the opposite view, considering that, among other things, the physical distance between the individuals involved in the relationship may be liberating, which may considerably ease communication (e.g., Walther, Loh \& Granka, 2005).

These contrasting views reflect above all conflicting philosophies regarding human interactions (Duck, 1994, 2007). As a result, we expected to find at least three different positions regarding the kind of relationship that one can expect to create using online dating services: two completely opposite views and a middle-ground view (Mullet et al., 2012). For some participants, probably a minority in 2017, creating relationships through the internet would always be impossible or at least very difficult. For other participants, creating any kind of relationship, from simple friendship to compassionate love, would be possible. Finally, for the third group of participants, probably a majority, it would depend on the kind of relationship that is desired. For example, creating sex-centered short-term relationships (romantic love) would be easier than creating long-term relationships involving strong feelings and sentiments (compassionate love). We also expected that these positions would be associated with participants' demographic characteristics and with their past or current use of online dating services.

\section{Method}

\section{Participants}

Eighty-two unpaid French participants (42 females and 40 males) participated in the present study. Their mean age was 33.61 years ( $S D=$ 13.05 , range $=21-65$ ). All participants lived in the area of Toulouse, in the Southwest of France. Data was gathered in 2017 using snowball sampling, whereby the author personally knows the first round of participants (from her circle of friends or acquaintances), whom after participating help her to find more people to participate, and so on. Other demographic characteristics are shown in Table 1.

\section{Table 1}

Demographic Characteristics of the Sample. Composition of Each Cluster

\begin{tabular}{|c|c|c|c|c|c|}
\hline \multirow{2}{*}{$\begin{array}{l}\text { Demographic } \\
\text { Characteristic }\end{array}$} & \multicolumn{4}{|c|}{ Cluster } & \multirow[b]{2}{*}{ Total } \\
\hline & Doubtful & $\begin{array}{l}\text { Depends on Duration } \\
\text { and Sentiments }\end{array}$ & $\begin{array}{l}\text { Always Quite } \\
\text { Possible }\end{array}$ & Undeterm. & \\
\hline \multicolumn{6}{|c|}{ 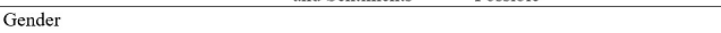 } \\
\hline Male & $8(20)^{\mathrm{a}}$ & $12(30)$ & $11(28)$ & $9(22)$ & 40 \\
\hline Female & $3(7)^{a}$ & $10(24)$ & $14(33)$ & $15(36)$ & 42 \\
\hline \multicolumn{6}{|l|}{ Age } \\
\hline$<30$ Years & $4(10)$ & $13(33)$ & $12(30)$ & $11(27)$ & 40 \\
\hline $30+$ years & $7(17)$ & $9(21)$ & $13(31)$ & $13(31)$ & 42 \\
\hline \multicolumn{6}{|l|}{ Marital Situation } \\
\hline Single & $0(0)^{\mathrm{ab}}$ & $5(29)$ & $8(47)$ & $4(24)$ & 17 \\
\hline Cohabiting & $6(17)^{\mathrm{a}}$ & $10(29)$ & $9(26)$ & $10(28)$ & 35 \\
\hline Married & $4(17)^{b}$ & $7(31)$ & $5(22)$ & $7(30)$ & 23 \\
\hline Separated & $1(14)$ & $0(0)$ & $3(43)$ & $3(43)$ & 7 \\
\hline \multicolumn{6}{|c|}{ Current Partner Met Through Internet } \\
\hline No & $7(17)$ & $13(31)$ & $12(28)$ & $10(24)$ & 42 \\
\hline Yes & $3(19)$ & $4(25)$ & $2(12)^{a}$ & $7(44)$ & 16 \\
\hline Not Applicable & $1(4)$ & $5(21)$ & $11(46)^{\mathrm{a}}$ & $7(29)$ & 24 \\
\hline \multicolumn{6}{|c|}{ Member of a Meeting Site } \\
\hline Never & $5(12)$ & $13(33)$ & $13(33)$ & $9(22)$ & 40 \\
\hline Has Been & $6(18)$ & $5(15)^{\mathrm{a}}$ & $10(29)$ & $13(38)$ & 34 \\
\hline Currently & $0(0)$ & $4(50)^{\mathrm{a}}$ & $2(25)$ & $2(25)$ & 8 \\
\hline \multicolumn{6}{|c|}{ Experience of a Lasting Relationship } \\
\hline Never & $3(15)$ & $3(15)$ & $7(35)$ & $7(35)$ & 20 \\
\hline Yes & $3(14)$ & $6(27)$ & $5(23)$ & $8(36)$ & 22 \\
\hline Not Applicable & $5(12)$ & $13(33)$ & $13(33)$ & $9(22)$ & 40 \\
\hline Total & 11 & 22 & 25 & 24 & 82 \\
\hline
\end{tabular}

Note. Figures with the same exponent are significantly different, $p<0.10$

\section{Material}

The material consisted of 72 cards showing a story of a few lines depicting a kind of relationships someone expects to be able to 
create using dating online services. Five critical items of information were provided: (a) the user's gender, (b) the user's age (23 years, 37 years, or 53 years), (c) the type of relationship expected (friendship vs. intimate), (d) the expected duration of the relationship (short term vs. long term), and (d) the level of personal, affective involvement in the relationship (no affective involvement, strong affective involvement passion, or openness to the possibility of affective involvement). The 72 stories were obtained by the orthogonal crossing of the five factors: $2 \times 3$ $\times 2 \times 2 \times 3=72$.

A sample story is the following: "Lea is 21 years old. She is single. As she does not plan to create, at this time, a lasting relationship, she would like to meet someone with whom to share intimate moments. She does not necessarily seek to create a romantic relationship, but she might possibly be open to the idea. To what extent do you think that Lea can expect creating such a relationship using an on-line dating service?" The response scale was a 30-point scale with "Not at all possible" (1) at the left extreme and "Completely possible" (30) at the right extreme.

\section{Procedure}

Each participant was tested individually in a calm environment. The procedure followed Anderson's recommendations for this kind of study (Anderson, 2008, 2016, 2018). They took 35 to 50 minutes to complete the whole task.

\section{Results}

To look for groupings of participants, a cluster analysis was performed on the raw data (Hofmans \& Mullet, 2013). Four clusters of participants were identified. An ANOVA was conducted on the whole set of data with a design of Cluster $\mathrm{x}$ Gender x Age x Type of relationship x Duration x Sentiments, $4 \times 2 \times 3 \times 2 \times 2 \times 3$. As the Cluster effect and two interactions involving the Cluster factor were significant, four separate ANOVAs were conducted on each cluster with an Age x Type of relationship x Duration x Sentiments, 4 $\times 2 \times 3 \times 2 \times 2 \times 3$ design. The main results are shown in Appendix A.

The first cluster $(N=11)$ was the expected cluster of participants who considered that creating a relationship using a dating service was at best difficult. The mean rating was 11.87; that is closer to the left anchor than to the right anchor of the response scale. As shown in Table 1 , females and single participants were less often members of this cluster than males and nonsingle participants.

The second cluster $(N=22)$ was the expected cluster of participants who considered that circumstances mattered. Ratings were higher (a) when the individual was younger $(M=18.82)$ than when the individual was older $(M=17.28)$, and when the level of expected involvement was undetermined $(M=20.21)$ than in both other cases $(M=16.82)$.

\section{Figure 1}

Three of the four clusters. Rating are on the $y$-axis. Age is on the $x$-axis. Each curve corresponds to one level of emotional involvement.
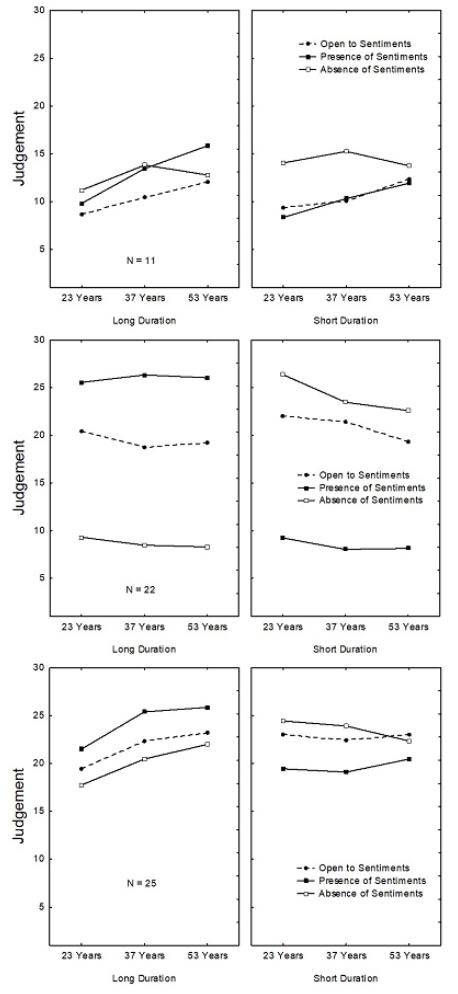

More importantly, the Duration x Sentiment interaction was significant. When the individual 
desired to create a lasting relationship, the effect of the sentiment factor was positive. Rating was higher in case of high level of involvement (M $=25.98)$ than in case of minimal involvement $(M=8.69)$. When the individual did not wish to create a lasting relationship, the effect of the sentiment factor was negative. Rating was lower in case of high level of involvement $(\mathrm{M}=$ 8.47) than in case of minimal involvement ( $M$ $=24.15)$. As shown in Table 1, participants who were currently using dating services were more often members of this cluster than former users of dating services.

The third cluster $(N=25)$ was the expected cluster of participants who considered that creating a relationship using a dating service was, in all circumstances, quite easy. The mean rating was 22.01; that is closer to the right anchor than to the left anchor of the response scale. As shown in Table 1, participants who met their current partner using dating services were less often members of this cluster than other participants.

The fourth cluster $(N=24)$ was unexpected. The mean rating was 18.35 ; that is close to the middle of the response scale. Ratings did not vary much as a function of circumstances. This cluster was, as a result, called Undetermined.

\section{Discussion}

As expected, contrasting positions were found. A minority of participants (13\%) considered that creating a relationship using dating services was never very easy. These participants were, in their majority, males. Unsurprisingly, they were never single, and no one currently used online dating services. As also expected, a plurality of participants (27\%) considered that creating, through the use of online dating services, either long-term romantic relationships (the consummate love or fatuous love categories in Sternberg's triangular model) or short-term, more "utilitarian" relationships (collaboration or occasional friendship) was considerably easier than creating either short-term romantic relationships (romantic love or infatuated love) or long-term, more "utilitarian" relationships (enduring friendship). This is a common sense finding; people tend to think that someone who desires to involve him/herself into a relationship strongly also wishes it to be a reasonably lasting one. Emotionally investing oneself into a relationship that fails to last may be the source of considerable suffering heartache (Wittstein et al., 2005).

However, and apparently contrary to common sense, another plurality of participants (30\%) considered that creating any kind of relationship was quite possible. These participants disconnected the commonly admitted association between the duration of a relationship and level of emotional involvement. In other words, they considered that creating a passionate but short-lived relationship of the kind described by the infatuated or romantic love categories suggested by Sternberg was not more difficult than creating any other kind of relationships. These participants probably referred, for judging, to the popular concept of "coup de foudre" (love at first sight). For some participants, who spontaneously expressed their views during the experiment, some people navigate through the internet looking for shortlived passionate experiences because they like the unique excitement provided by such experiences.

Finally, more than one-quarter of participants (29\%) did not express any strong view regarding the possibility to create relationships using online dating services. If the participants in this cluster had given only one response to a single scenario or a generic questiontheir responses would have been considered as expressing moderate agreement with the question asked. Having them respond to multiple stories allowed researchers were distinguishing absence of an opinion from a moderate level of agreement; that is, it suggested that participants in this group did not actually make judgments, but merely put marks at the same place (more or less) in each case. This last finding provides thus a methodological lesson. 


\section{References}

Anderson, N. H. (2018). Moral science. New York, NY: Psychology Press.

Anderson, N. H. (2016). Information integration theory: Unified psychology based on three mathematıcal laws. Universitas Psychologica, 15(3), 1-7. https://doi.org/10.11144/Javeria na.upsy15-3.iitu

Anderson, N. H. (2018). Unified social cognition. New York, NY: Psychology Press.

Cummings, J., Butler, B., \& Kraut, R. (2002). The quality of online social relationships. Communications of the ACM, 45(7), 103-108. https://doi.org/10.1145/514236.5 14242

Duck, S. (1994). Meaningful relationships: Talking, sense, and relating. Thousand Oaks, CA: Sage.

Duck, S. (2007). Human relationships. Thousand Oaks, CA: Sage.

Falconi, A., \& Mullet, E. (2003). Cognitive algebra of love through the adult life. International Journal of Aging and Human Development, 57(3), 277-292. https://doi.or g/10.2190/NPQH-MDLX-F48U-AA35

Hofmans, J., \& Mullet, E. (2013). Towards unveiling individual differences in different stages of information processing: A clustering-based approach. Quality and Quantity, 47(1), 455-464. https://doi.org/10 $.1007 / \mathrm{s} 11135-011-9529-7$

Kang, T., \& Hoffman, L. H. (2011). Why would you decide to use an online dating site? Factors that lead to online dating. Communication Research Reports, 28, 205-213. https://doi.org/10.1080/08824096 .2011 .566109

Morales, G. E., Lopez, E. O., Campos, C., Charles, D., Mezquita, Y. N., \& Mullet, E. (2015). Conceptualization of romantic love among adults with Down's syndrome. Sexuality E Disability, 33(3), 339-348. http: //dx.doi.org/10.1007/s11195-014-9368-2

Mullet, E., Sorum, P. C., Teysseire, N., Nann, S., Morales, G. E., Ahmed, R., ... Muñoz-Sastre, M. T. (2012). Functional Measurement in the field of empirical bioethics. Psicologica: International Journal of Methodology and Experimental Psychology, 33, 665-681. Retrieved from https://files.eri c.ed.gov/fulltext/EJ980500.pdf

Sternberg, R. J. (1986). A triangular theory of love. Psychological Review, 93(2), 119-135. http://dx.doi.org/10.1037/0033-2 95X.93.2.119

Vera Cruz, G. (2019). Comparing Mozambican and French People's conceptualization of romantic love. Universitas Psychologica, 18(1), 1-XX. https://doi.org/10.11144/Javer iana.upsy18-1.cmfp,

Walther, J. B., Loh, T., \& Granka, L. (2005). Let me count the ways: The interexchange of verbal and nonverbal cues in computermediated face-to-face affinity. Journal of Language and Social Psychology, 24(1), 3665. https://doi.org/10.1177/0261927X0427 3036

Wittstein, I. S., Thiemann, D. R., Lima, J. A. C., Baughman, K. L., Schulman, S. P., Gerstenblith, G., ...Champion, H. C. (2005). Neurohumoral features of myocardial stunning due to sudden emotional stress. New England Journal of Medicine, 352 (6), 539-548. https://doi.org/1 $0.1056 /$ NEJMoa043046

\section{Appendix A}

\begin{tabular}{|c|c|c|c|c|c|}
\hline Cluster and Factor & $D f$ & MS & $F$ & $p$ & $\eta^{2} p_{p}$ \\
\hline \multicolumn{6}{|l|}{ Cluster : Doubtful } \\
\hline Gender & 1 & 140.85 & 11.91 & 0.01 & 0.54 \\
\hline Age & 2 & 567.77 & 2.12 & 0.15 & 0.17 \\
\hline Duration & 1 & 16.99 & 0.22 & 0.65 & 0.02 \\
\hline Type of Relation & 1 & 764.25 & 3.48 & 0.09 & 0.26 \\
\hline Sentiments & 2 & 590.11 & 3.53 & 0.05 & 0.26 \\
\hline \multicolumn{6}{|c|}{ Cluster : Depends on Duration and Sentiments } \\
\hline Gender & 1 & 10.33 & 0.31 & 0.58 & 0.02 \\
\hline Age (A) & 2 & 314.85 & 9.12 & 0.001 & 0.31 \\
\hline Duration (D) & 1 & 15.08 & 0.09 & 0.77 & 0.00 \\
\hline Type of Relation & 1 & 288.97 & 6.37 & 0.02 & 0.24 \\
\hline Sentiments (S) & 2 & 2002.07 & 22.19 & 0.001 & 0.53 \\
\hline $\mathrm{A} \times \mathrm{D}$ & 2 & 120.61 & 8.39 & 0.001 & 0.30 \\
\hline $\mathrm{DxS}$ & 2 & 34484.75 & 128.86 & 0.001 & 0.87 \\
\hline $\mathrm{G} \times \mathrm{A} \times \mathrm{D}$ & 2 & 138.12 & 6.28 & 0.001 & 0.24 \\
\hline \multicolumn{6}{|c|}{ Cluster : Always Quite Possible } \\
\hline Gender & 1 & 38.04 & 1.13 & 0.30 & 0.05 \\
\hline Age (A) & 2 & 514.79 & 2.69 & 0.08 & 0.11 \\
\hline Duration (D) & 1 & 0.38 & 0.00 & 0.95 & 0.00 \\
\hline Type of Relation & 1 & 6.91 & 0.07 & 0.79 & 0.00 \\
\hline Sentiments (S) & 2 & 27.20 & 0.27 & 0.77 & 0.01 \\
\hline$A \times D$ & 2 & 789.17 & 24.48 & 0.001 & 0.53 \\
\hline $\mathrm{D} \times \mathrm{S}$ & 2 & 2381.55 & 17.38 & 0.001 & 0.44 \\
\hline
\end{tabular}

\section{Notes}

* Research article. 